удК 616.314-084(477.42)

DOI 10.11603/2311-9624.2017.3.8032

\author{
(C). М. Косенко ${ }^{1}$, С. М. Чепюк ${ }^{2}$
}

КВН3 «Житомирський інститут медсестринства» Житомирської обласної ради ${ }^{1}$

КУ «Житомирська міська стоматологічна поліклініка № 1»²

\title{
Перспективність надання гігієністом зубним профілактичної стоматологічної допомоги населенню м. Житомира
}

Резюме. Профілактична медицина покладена в основу розвитку систем охорони здоров’я країн Європейського Союзу, а вкладені кошти в попереджувальний напрямок визнано найефективнішими інвестиціями в індустрію збереження та зміцнення здоров'я. Профілактичний напрямок - один 3 найважливіших у сучасній стоматології.

Мета дослідження - проаналізувати лікувально-профілактичні показники діяльності Комунальної установи «Житомирська міська стоматологічна поліклініка № 1» та визначити шляхи поліпшення первинної профілактики.

Матеріали і методи. Проаналізовано річні звіти терапевтичного та хірургічного відділень КУ «Житомирська міська стоматологічна поліклініка № 1» за період з 2015 до 2016 р.; проведено опитування 115 пацієнтів закладу щодо методики чищення зубів та використання предметів і засобів, необхідних для догляду за порожниною рота. У дослідженні використано такі методи: бібліосемантичний, системного аналізу та логічного узагальнення, опитування, математичної обробки зібраних даних.

Результати досліджень та їх обговорення. Цифровий матеріал, що відтворює роботу Житомирської міської стоматологічної поліклініки № 1 (ЖМСП № 1), переконує, що лікарі закладу виконують значний обсяг втручань, пов'язаних із санацією порожнини рота, використовуючи сучасні пломбувальні матеріали та методи діагностики. Проте (в основному) вся робота спрямована на вторинну профілактику. Як наслідок, щорічно фіксують велику кількість видалених зубів із приводу ускладненого карієсу (23 370-23 898), значну кількість пацієнтів 3 проявами захворювань пародонта (3521-3766). На диспансерному обліку перебуває 94 пацієнти з передпухлинною патологією. Враховуючи, що гігієнічне навчання та виховання населення є однією з головних складових первинної профілактики, ми провели опитування 115 пацієнтів із ЖМСП № 1. Результати дослідження свідчать, що пацієнти стоматологічної установи недостатньо обізнані з питань застосування предметів та засобів, необхідних для виконання гігієнічних процедур. Усі респонденти готові вкладати кошти в запобіжні стоматологічні заходи, аніж у терапевтичне та хірургічне лікування зубів. Досягти позитивної динаміки в показниках, що відтворюють стоматологічне здоров’я, можливо лише у разі первинного попередження карієсу та захворювань пародонта. Введення в штатний розпис стоматологічних закладів посад гігієніста зубного дозволило б не тільки повноцінно проводити первинну профілактику, а й звільнити час висококваліфікованих лікарів-стоматологів для проведення складних маніпуляцій у порожнині рота. Висновки. У Житомирській міській стоматологічній поліклініці № 1 відсутні посади зубних гігієністів, а тому і робота закладу спрямована на вторинну профілактику захворювань порожнини рота. Низький рівень санітарної культури населення м. Житомира тісно взаємопов'язаний із показниками стоматологічного здоров’я. Подальший розвиток та реформування стоматологічної допомоги потребує підготовки нового покоління висококваліфікованих молодших медичних спеціалістів (гігієністів зубних). Залучення гігієністів зубних до надання профілактичної допомоги дозволить поліпшити якість профілактичних стоматологічних послуг та досягти зниження стоматологічної захворюваності.

Ключові слова: гігієніст зубний; первинна профілактика; стоматологічна допомога.

\section{(C). М. Косенко ${ }^{1}$, С. М. Чепюк ${ }^{2}$}

КВУЗ «Житомирский институт медсестринства» Житомирского областного совета ${ }^{1}$

КУ «Житомирская городская стоматологическая поликлиника № 1 » $^{2}$

\section{Перспективность предоставления гигиенистом зубным профилак- тической стоматологической помощи населению г. Житомира}

Резюме. Профилактическая медицина положена в основу развития систем здравоохранения стран Европейского Союза, а вложенные средства в предупредительное направление признано наиболее 
эффективными инвестициями в индустрию сохранения и укрепления здоровья. Профилактическое направление - одно из важнейших в современной стоматологии.

Цель исследования - проанализировать лечебно-профилактические показатели деятельности Коммунального учреждения “Житомирская городская стоматологическая поликлиника № 1» и определить пути улучшения первичной профилактики.

Материалы и методы. Были проанализированы годовые отчеты терапевтического и хирургического отделений КУ «Житомирская городская стоматологическая поликлиника № 1» за период с 2015 по 2016 г.; проведен опрос 115 пациентов заведения относительно методики чистки зубов и использования предметов и средств, необходимых при уходе за полостью рта. В исследовании использованы следующие методы: библиосемантический, системного анализа и логического обобщения, опрос, математической обработки собранных данных.

Результаты исследований и их обсуждение. Цифровой материал, воспроизводящий работу Житомирской городской стоматологической поликлиники № 1 (ЖГСП № 1), убеждает, что врачи учреждения выполняют значительный объем вмешательств, связанных с санацией полости рта, используя современные пломбировочные материалы и методы диагностики. Однако (в основном) вся работа направлена на вторичную профилактику. Как следствие, ежегодно фиксируется большое количество удаленных зубов по поводу осложненного кариеса (23 370-23 898), значительное количество пациентов с проявлениями заболеваний пародонта (3521-3766). На диспансерном учете находится 94 пациента с предопухолевой патологией. Учитывая, что гигиеническое обучение и воспитание населения является одной из главных составляющих первичной профилактики, мы провели опрос 115 пациентов с ЖГСП № 1. Результаты исследования показывают, что пациенты стоматологического учреждения недостаточно осведомлены по вопросам применения предметов и средств, необходимых для выполнения гигиенических процедур. Все респонденты готовы вкладывать средства в предупредительные стоматологические мероприятия, а не в терапевтическое и хирургическое лечение зубов. Достичь положительной динамики в показателях, которые воспроизводят стоматологическое здоровье, возможно только в случае первичного предупреждения кариеса и заболеваний пародонта. Введение в штатное расписание стоматологических учреждений должностей гигиениста зубного позволило бы не только полноценно проводить первичную профилактику, но и освободить время высококвалифицированных врачей-стоматологов для проведения сложных манипуляций в полости рта.

Выводы. В Житомирской городской стоматологической поликлинике № 1 отсутствуют должности зубных гигиенистов, поэтому работа учреждения направлена на вторичную профилактику заболеваний полости рта. Низкий уровень санитарной культуры населения г. Житомира тесно взаимосвязан с показателями стоматологического здоровья. Дальнейшее развитие и реформирование стоматологической помощи требует подготовки нового поколения высококвалифицированных младших медицинских специалистов (гигиенистов зубных). Привлечение гигиенистов зубных к оказанию профилактической помощи позволит улучшить качество профилактических стоматологических услуг и добиться снижения стоматологической заболеваемости.

Ключевые слова: гигиенист зубной; первичная профилактика; стоматологическая помощь.

\author{
COV. M. Kosenko' ${ }^{1}$ S. M. Chepiuk ${ }^{2}$
}

Zhytomyr Nursing Institute of Zhytomyr Regional Council ${ }^{1}$

Zhytomyr City Dental Hospital No.12

\title{
Prospects of rendering preventive dental care to residents of Zhytomyr city by a hygienist
}

Summary. Preventive medicine is the basis for the development of health care systems in the European Union, and investment in prevention is recognized as the most effective investment in the industry of preserving and improving health. Prophylactic direction - one of the most important in modern dentistry.

The aim of the study - analysis of treatment and prevention performance indicators of Municipal Institution Zhytomyr City Dental Hospital No.1 and definition of methods for improving the primary prevention.

Materials and Methods. We analyzed the annual reports of internal medicine and surgical departments of Zhytomyr City Dental Hospital No. 1 for the period from 2015 till 2016; we held a poll of 115 patients of the establishment regarding the methods for teeth cleaning and using the accessories and means necessary for oral cavity care. The following methods were used: bibliosemantic, system analysis and logical concluding, interview, and mathematical processing of the collected data. 
Results and Discussion. Numeric materials reflecting the work of Zhytomyr City Dental Hospital No.1 indicate that doctors employed in the establishment conduct numerous maneuvers related to oral cavity sanitation using modern filling materials and diagnostic methods. However (and predominantly), all the work is directed at secondary prevention. As a result, annually a lot of teeth are removed due to complex caries (23.37023.898), and there are a lot of patients with signs of periodontal diseases (3.521-3.766). Dispensary for diseases includes 94 patients with pre-tumor pathology. Considering that public hygienic teaching and education is one of the main components of primary treatment, we held a poll involving 115 patients of Zhytomyr City Dental Hospital No. 1. Study results indicate that the patients of the dental care entity have insufficient knowledge on using the accessories and means necessary for hygienic procedures. All the respondents are more ready to invest into prevention care than internal medicine and surgical dental treatment. It is possible to reach an upward trend in dental health indicators only with primary caries and periodontal diseases prevention. Adding hygienist in the staffing list of dental care entities would allow not only for comprehensive primary prevention, but would also unload the high-class dentists enabling them to conduct more complex oral cavity operations.

Conclusions. Zhytomyr City Dental Hospital No. 1 employs no hygienists, that is why its work is aimed at secondary treatment of oral cavity diseases. Low sanitary culture level of Zhytomyr residents is tightly connected with dental health indicators. Further development and reforming of dental care demands training of the new generation of highly qualified junior medical staff (hygienists). Involving of hygienists in treatment care allows improving the quality of preventive dental services and decreasing dental diseases incidence rate.

Key words: hygienist; primary treatment; dental care.

Вступ. Профілактична медицина покладена в основу розвитку систем охорони здоров'я країн Європейського Союзу, а вкладені кошти в попереджувальний напрямок визнано найефективнішими інвестиціями в індустрію збереження та зміцнення здоров’я [1]. Профілактичний напрямок - один 3 найважливіших у сучасній стоматології [2].

Світовий досвід переконливо свідчить про необхідність застосування комплексної масової системи профілактики захворювань порожнини рота 3 метою запобігання або усунення подальшого розвитку карієсу та захворювань пародонта [3, 4]. Превентивні та своєчасні заходи здатні суттєво вплинути на рівень стоматологічної захворюваності, зменшити показники поширеності та інтенсивності основних стоматологічних захворювань [5].

Упровадження програм профілактики (з акцентом на первинну профілактику) в Україні гальмується внаслідок низки причин, однією 3 яких є відсутність фахівців (гігієністів зубних), професійна діяльність яких спрямовується на збереження стоматологічного здоров'я, формування у населення навичок раціонального догляду за порожниною рота.

Метою дослідження було проаналізувати лікувально-профілактичні показники діяльності Комунальної установи «Житомирська міська стоматологічна поліклініка №1» та визначити шляхи поліпшення первинної профілактики.

Для реалізації мети були поставлені наступні завдання: вивчити літературні джерела 3 теми дослідження; розглянути основні показники роботи Житомирської міської стоматологічної поліклініки № 1; опитати пацієнтів стоматологічної установи щодо виконання правил гігієни порожнини рота; обгрунтувати необхідність введення посад гігієніста зубного до штатних розписів стоматологічних установ.

Матеріали і методи. Проаналізовано річні звіти терапевтичного та хірургічного відділень КУ «Житомирська міська стоматологічна поліклініка № 1» за період з 2015 до 2016 р.; проведено опитування 115 пацієнтів закладу щодо методики чищення зубів та використання предметів і засобів, необхідних для догляду за порожниною рота.

У дослідженні використано такі методи: бібліосемантичний, системного аналізу та логічного узагальнення, опитування, математичної обробки зібраних даних.

Результати досліджень та їх обговорення. Комунальна установа «Житомирська міська стоматологічна поліклініка № 1» - спеціалізований сучасний медичний заклад, лікарі якого надають терапевтичну та хірургічну стоматологічну допомогу населенню м. Житомира. Загальна кількість відвідувань у 2016 р. відповідала показнику 125503 (табл. 1). У місті Житомир (станом на 1 лютого 2015 р.) мешкає 269870 осіб. Близько 20 \% населення обласного центру протягом року звертається до фахівців Житомирської міської стоматологічної поліклініки № 1 з приводу лікування карієсу, захворювань пародонта та слизової оболонки порожнини рота. 
Цифровий матеріал, що відтворює роботу Житомирської міської стоматологічної поліклініки № 1, переконує, що лікарі закладу виконують значний обсяг втручань, пов'язаних із санацією порожнини рота, використовуючи сучасні пломбувальні матеріали та методи діагностики. Проте (в основному) вся робота спрямована на вторинну профілактику. Як наслідок, щорічно фіксують велику кількість видалених зубів з приводу ускладненого карієсу (23 370-23 898), значну кількість пацієнтів із проявами захворювань пародонта (3521-3766). На диспансерному обліку знаходиться 94 пацієнти з передпухлинною патологією.
Основну увагу фахівці закладу звертають на оздоровлення порожнини рота населення м. Житомира (табл. 2). У 2016 р. проведено 2928 амбулаторних операцій, проліковано 87735 зубів, сановано 26380 осіб. Показники роботи поліклініки як кількісні, так і якісні є на рівні середньообласних та середньоміських.

Враховуючи, що гігієнічне навчання та виховання населення $€$ однією $з$ головних складових первинної профілактики, ми провели опитування 115 пацієнтів із ЖМСП № 1. Результати дослідження свідчать, що пацієнти стоматологічної установи недостатньо обізнані з питань застосування предметів та засобів,

Таблищя 1. Показники лікувально-профілактичної роботи КУ «Житомирська міська стоматологічна поліклініка № 1» за період з 2015 до 2016 р.

\begin{tabular}{|c|c|c|c|}
\hline \multirow{2}{*}{ Показник роботи закладу } & \multicolumn{2}{|c|}{ Рік } & \multirow{2}{*}{$\begin{array}{c}\text { Порівняльний аналіз } \\
\text { показників 2016-2015 рр., } \\
\%\end{array}$} \\
\hline & 2015 & 2016 & \\
\hline Усього відвідувань & 133000 & 125503 & $-5,6$ \\
\hline У тому числі первинних пацієнтів & 47103 & 43786 & -7 \\
\hline Отримали невідкладну допомогу & 23961 & 22770 & -5 \\
\hline Усього запломбовано зубів & 91629 & 87735 & $-4,2$ \\
\hline Запломбовано зубів з приводу карієсу & 58581 & 54278 & $-7,3$ \\
\hline $\begin{array}{l}\text { Запломбовано зубів з приводу } \\
\text { ускладненого карієсу }\end{array}$ & 28052 & 28330 & +1 \\
\hline $\begin{array}{l}\text { Кількість пацієнтів, яким проведено } \\
\text { курс лікування з приводу захворю- } \\
\text { вань пародонта }\end{array}$ & 3766 & 3521 & $-6,5$ \\
\hline Усього видалено зубів & 23898 & 23370 & $-2,2$ \\
\hline Проведено амбулаторних операцій & 3038 & 2928 & $-3,6$ \\
\hline Усього сановано & 29212 & 26380 & $-9,7$ \\
\hline
\end{tabular}

таблиия 2. Деякі показники діяльності КУ «Житомирська міська стоматологічна поліклініка № 1» за період з 2015 до 2016 р.

\begin{tabular}{|c|c|c|c|}
\hline \multirow{2}{*}{ Показник } & \multicolumn{2}{|c|}{ Рік } & \multirow{2}{*}{$\begin{array}{c}\text { Нормативний } \\
\text { показник }\end{array}$} \\
\hline & 2016 & 2015 & \\
\hline $\begin{array}{l}\text { Питома вага санованих від загальної кількості } \\
\text { первинних хворих, \% }\end{array}$ & 60,2 & 62 & 50 \\
\hline Кількість відвідувань на одну сановану особу & 4,7 & 4,5 & 3,7 \\
\hline $\begin{array}{l}\text { Питома вага пломб із сучасних композитних } \\
\text { матеріалів, \% }\end{array}$ & 83,6 & 79 & 40 \\
\hline $\begin{array}{l}\text { Питома вага вилікуваного ускладненого карієсу } \\
\text { за одне відвідування, \% }\end{array}$ & 52,4 & 51,4 & 35 \\
\hline $\begin{array}{l}\text { Питома вага оперованих у плановому порядку } \\
\text { до загальної кількості операційних втручань на } \\
\text { амбулаторному стоматологічному хірургічному } \\
\text { прийомі, \% }\end{array}$ & 32,2 & 31,4 & 20 \\
\hline $\begin{array}{l}\text { Кількість операцій, виконаних амбулаторно на } \\
10 \text { тис. населення }\end{array}$ & 176 & 184 & 100 \\
\hline Співвідношення вилікуваних та видалених зубів & $3,7: 1$ & $3,8: 1$ & - \\
\hline
\end{tabular}


необхідних для виконання гігієнічних процедур. Тільки 22,5 \% опитаних користуються щодня зубною щіткою, пастою, флосами та ополіскувачами. При виборі засобів для гігієнічного догляду за порожниною рота $42,5 \%$ пацієнтів звертають увагу на вартість, 32,5 \% на дизайн упаковки продукції. Лише 12,5 \% опитаних щодня користуються предметами інтердентальної гігієни. Необхідно зауважити, що всі респонденти готові вкладати кошти в запобіжні стоматологічні заходи, аніж у терапевтичне та хірургічне лікування зубів.

Досягти позитивної динаміки в показниках, що відтворюють стоматологічне здоров'я (зменшення кількості осіб із патологією порожнини рота), можливо лише у разі первинного попередження карієсу та захворювань пародонта. Реформування системи охорони здоров'я України вимагає нових підходів до роботи фахівців стоматологічного профілю. Особливого значення в наш час набуває саме первинна профілактика.

Введення в штатний розпис стоматологічних закладів посад гігієніста зубного дозволило б не тільки повноцінно проводити первинну профілактику, а й звільнити час висококваліфікованих лікарів-стоматологів для проведення складних маніпуляцій у порожнині рота. В межах своєї компетентності гігієніст зубний може виконувати такі завдання: професійне чищення зубів та їх вибілювання, герметизацію фісур, застосовувати ремінералізуючі розчини, покривати зуби фтор-лаком. Значний відсоток робочого часу молодші спеціалісти кваліфікації «гігієніст зубний» відводять гігієнічному навчанню та вихованню населення. Для кожного пацієнта складаються індивідуальні оздоровчі програми та надаються рекомендації щодо вибору предметів і засобів догляду за порожниною рота. Всю підготовчу роботу до подальшого терапевтичного, хірургічного, ортопедичного та ортодонтичного лікувань проводять молодші спеціалісти 5.12010104 «Стоматологія».

Професійна підготовка фахівців у галузі профілактичної стоматології за кордоном розпочалася ще в XIX ст. Уперше гігієністи зубні з'явилися в 1843 р. у США [6]. В наш час у 30 країнах світу ці спеціалісти планують та

\section{Список літератури}

1.Профілактична медицина-моднегаслочиновапарадигма охорони здоров'я? [Електронний ресурс]. - організовують оздоровчі стоматологічні заходи. У країнах Європейського Союзу відвідування гігієніста стало нормою життя та є одним 3 принципів страхової медицини. В Україні ця філософія поки що тільки на етапі осмислення та формування.

Сучасний рівень надання стоматологічних послуг передбачає комплексний підхід у лікуванні пацієнтів, який необхідно починати 3 навчання гігієни порожнини рота та закінчувати контролем за якістю проведених гігієнічних процедур. Повноцінна гігієна порожнини рота дає можливість (у більшості випадків) уникнути процесів руйнування твердих тканин зуба, стабілізує та усуває запальні явища в тканинах пародонта, продовжує терміни служби ортопедичних конструкцій, прискорює регенерацію тканин після хірургічних втручань тощо.

Залучення гігієністів зубних до проведення профілактичних заходів, запровадження ефективної моделі системи стоматологічної диспансеризації за участю фахівців спеціальності 5.12010104 «Стоматологія» допоможуть поліпшити стоматологічне здоров'я населення.

Висновки. 1. У Житомирській міській стоматологічній поліклініці № 1 відсутні посади зубних гігієністів, а тому і робота закладу спрямована на вторинну профілактику захворювань порожнини рота.

2. Низький рівень санітарної культури населення м. Житомира тісно взаємопов’язаний з показниками стоматологічного здоров'я.

3. Подальший розвиток та реформування стоматологічної допомоги потребує підготовки нового покоління висококваліфікованих молодших медичних спеціалістів (гігієністів зубних).

4. Залучення гігієністів зубних до надання профілактичної допомоги дозволить поліпшити якість профілактичних стоматологічних послуг та досягти зниження стоматологічної захворюваності.

Перспективи подальших досліджень. У подальшому необхідно глибоко та всебічно проаналізувати світовий досвід підготовки гігієністів зубних з метою становлення спеціальності в Україні. Встановити чітке розмежування функціональних обов'язків між лікаремстоматологом та гігієністом зубним.

Режим доступу: http://www.vz.kiev.ua/profilaktichnamedicina-modne-gaslo-chi-nova-paradigma-oxoronizdorovya/. 
2. Кузняк Н. Б. Перші кроки на шляху відновлення профілактичної стоматології в Україні / Н. Б. Кузняк, О. І. Годованець // Клінічна анатомія та оперативна хірургія. - 2014. - Т. 13, № 2. - С. 120-123.

3. Олсеан Г. Роль стоматологического гигиениста в профилактике стоматологических заболеваний населения Швеции / Гуннар Олсеан : материалы международной конференции «Профилактика стоматологических заболеваний у детей» (Псков, 27-28 сентября 2007 г.). - Псков, 2007. - С. 165-166.

4. Супиев Т. К. Гигиенист стоматологический основной исполнитель программы профилактики стоматологических заболеваний у детей /

\section{References}

1. Profilaktychna medytsyna - modne haslo chy nova paradyhma okhorony zdorovia? [Preventive medicine - just a trendy slogan or a new public health care paradigm?]. www.vz.kiev.ua. Retrieved from: http:// www.vz.kiev.ua/profilaktichna-medicina-modne-gaslochi-nova-paradigma-oxoroni-zdorovya / [in Ukrainian]. 2. Kuzniak, N.B., \& Hodovanets, O.I. (2014). Pershi kroky na shliakhu vidnovlennia profilaktychnoi stomatolohii $\mathrm{v}$ Ukraini [First steps undertaken in an attempt to recover the preventive dentistry in Ukraine]. Klinichna anatomiia ta operatyvna khirurhiia - Clinical Anatomy and Operative Surgery, 13, 120-123 [in Ukrainian].

3. Olsean, H. (2007). Rol stomatologicheskogo gigiyenista $\mathrm{v}$ profilaktike stomatologicheskikh zabolevaniy naseleniya Shvetsyi [Significance of the dental hygienist for prevention of dental diseases among Swedish population]. Materyaly mezhdunarodnoy konferentsyi "Profilaktika stomatologicheskikh zabolevaniy u detey"Materials of the "Children's Dental Disease Prevention" International Conference. (pp. 165-166). Pskov [in Russian].
Т. К. Супиев, А. К. Абдыбекова, Е. К. Орманов : Международная научно-практическая конференция «Проблемы и перспективы развития стоматологической службы в Республике Казахстан». - Алматы, 2010. - С. 179-180.

5. Смоляр Н. I. Профілактика стоматологічних захворювань у дітей / Н. I. Смоляр, 3. П. Масний, Л. Г. Поліканова. - Львів : Світ, 2008. - 152 с.

6. Косенко В. М. Шляхи становлення професії гігієніст зубний: світовий досвід / В. М. Косенко, Г. С. Полчанова // Магістр медсестринства. - 2016. № 1(15). - C. 86-92.

4. Supiev, T.K., Abdybekova, A.K., Ormanov, E.K. (2010). Gigiyenist stomatologicheskiy - osnovnoy ispolnitel programmy profilaktiky stomatologicheskikh zabolevaniy $u$ detey [Dental hygienist as primary follower of the children's dental disease prevention program]. "Problemy stomatologii» Mezhdunarodnaya nauchno-prakticheskaya konferentsyya "Problemy $i$ perspekiyvy razvitiya stomatologicheskoy sluzhby $v$ Respublike Kazakhstan" - "Dentistry Related Problems». "Problems and Prospects of Dental Health Service Development in the Republic of Kazakhstan" International Research- Practice Conference. (pp. 179180). Almaty [in Russian].

5. Smoliar, N.I., Masnyi, Z.P., Polikanova, L.H. (2008). Profilaktyka stomatolohichnykh zakhvoriuvan u ditei [Children's dental disease prevention]. Lviv: Svit [in Ukrainian].

6. Kosenko, V.M., \& Polchanova, H.S. (2016). Shliakhy stanovlennia profesii hihiienist zubnyi: svitovyi dosvid [Milestones of dental hygienist occupation development: international practices]. Mahistr medsestrynstva Master of Nursing, (1), 86-92 [in Ukrainian]. 